\title{
In Vitro Effectiveness of Neem Oil (Azadirachta indica A. Juss) Shampoo as Anti Head Lice (Pediculus humanus capitis)
}

\author{
Norisca A. Putriana, Azizul Hakim, Patihul Husni, Taofik Rusdiana
}

Department of Pharmaceutical and Technology Pharmacy,

Faculty of Pharmacy, Universitas Padjadjaran, Bandung, West Java, Indonesia

\begin{abstract}
Head lice (Pediculus humanus capitis) is a parasite causing hair problem. The aim of this study was to evaluate in vitro effectiveness of the neem oil shampoo formulation as an anti head lice. We formulated four different concentration $(5 \%, 10 \%, 15 \%, 20 \%)$ o of neem oil) and evaluated the shampoo, included skin irritation test, pediculicidal, and ovicidal activity of the shampoo. Skin and eye irritation tests were carried out by applying $0.5 \mathrm{ml}$ shampoo to the skin and dripping $0.1 \mathrm{ml}$ into the eyes of newzealand white rabbits, respectively. The data were analyzed by using Kruskal Wallis and Mann Whitney. The primary irritation index of $5 \%, 10 \%, 15 \%$, and $20 \%$ neem oil shampoo respectively were $0.00 ; 0.0111 ; 0.222$; and 0.222 ; which categorized as very mild irritation. Only the $20 \%$ neem oil shampoo showed a mild irritation to the eyes (the degree of corneal opacity $\geq 1$ ) and recovered after 7 days of observation. All formulas of neem oil shampoo were effective as an anti lice, however, the $15 \%$ and $20 \%$ neem oil shampoo had similar effectivenes compared with $1 \%$ permethrin lotion. In conclusion, the $15 \%$ neem oil shampoo was the best anti head lice shampoo.

Keywords: Head lice, neem oil (Azadirachta indica A. Juss), shampoo
\end{abstract}

\section{Introduction}

Head lice or Pediculus humanus capitis is a parasite known as ectoparasites. Head lice are often found on hair and scalp, which are easily transmitted only through physical contact. $^{1}$

Head lice management is important to prevent secondary infections. ${ }^{2}$ People usually treat head lice problems by using topical products, including Ivermectin (semi-synthetic macrocyclic lactone $)^{3-6}$ and chemical compounds (organochlorides, natural and synthetic pyrethrins, carbamates), but these treatments may induce resistance. However, neem oil is an alternative herbal shampoo to treat head lice that have pediculicidal activity. ${ }^{3,7}$

The clinical trials of neem oil products are still limited to support therapeutic claims, but the use of neem plants has much developed. ${ }^{8}$ Neem plants contain several active substances, including azadiractin, nimbolides, nimbidin, nimbin, salanin, gedunin, meliacin, and valassin. Triterpene, an active metabolite of azadiractin, is effective $(90 \%)$ against head lice. ${ }^{9}$ Mechanism of action remains

Corresponding author: Norisca A. Putriana. Department of Pharmaceutical and Technology Pharmacy, Faculty of Pharmacy Universitas Padjdjaran. email: norisca@unpad.ac.id

Received: 25 November 2019. Revised: 20 December 2019. Published: 28 December 2019. 
unclear; however, neem oil works as appetite suppressan and cause death. ${ }^{10,11}$

Previously, a mortality rate study of neem oil was performed. The result showed that neem oil concentration of $20 \%$ was the most effective against head lice (mortality rate $100 \%$ in 120 minutes), while the same concentration killed $50 \%$ of the nits in 9 days. In vitro evaluation needs to be conducted to ensure the safety and effectiveness of the shampoo before being clinically used in human. Therefore, this study was conducted to evaluate safety and effectiveness of neem oil as an anti head lice.

\section{Methods}

This study was approved by the Health Research Ethics Commission of the Faculty of Medicine, Padjadjaran University, Indonesia (No. 444/UN6.KEP/EC/2018).

\section{Shampoo Formulation}

Certificated neem oil was obtained from Happy Green Co, Jakarta, Indonesia. The shampoo contained: $5 \%$ neem oil, $13.6 \%$ sodium lauryl sulfate, 4\% cocamidopropyl betaine, 5\% coco-glycoside, 10\% PEG-7 glyceryl cocoate, $7.6 \%$ PEG-40 hydrogenated castor oil, $0.2 \%$ guar hydroxypropyltrimonium chloride, 2\% glycerin, 3\% cocamide DEA, $4 \%$ acrylate co-polymer, $0.1 \%$ vitamin $\mathrm{E}$, $0.18 \%$ methylparaben, $0.02 \%$ propylparaben, $2 \%$ perfume (jasmine) and deionized water. The oil phase (vitamin E, PEG-7 glyceryl cocoate and PEG-40 hydrogenated castor oil) was placed in a beaker and stirred until homogenous. Water phase (guar hydroxypropyltrimonium chloride, glycerin, sodium lauryl sulfate, cocamidopropyl betaine, coco-glycoside and deionized water) were mixed until homogenous. Then, the oil and water phases were mixed until shampoo was formed. Methylparaben and propylparaben were dissolved in deionized water and poured into the shampoo base. Lastly, neem oil and perfume were added to the shampoo bases.

\section{Acclimatization of the animals}

New Zealand albino male rabbits (aged 6-8 weeks; weighed $1.5-2 \mathrm{~kg}$ ) were normally fed and maintained in a room with good air circulation, temperature, and lighting. The animals were acclimatized for five days and body weight were observed every day. The animals that lost more than $10 \%$ of their body weight during acclimatization were excluded.

\section{Acute dermal irritation test}

The fur of the rabbit was shaved on the back area of approximately $10 \times 15 \mathrm{~cm}$ or not less than $10 \%$ of the body surface for the exposure place of test preparation. Shaving started from the shoulder blades area (shoulder) to the groin bone (waist bone) and half down the body on each side. The irritation test was carried out by applying $0.5 \mathrm{ml}$ of shampoo to the back of the rabbit and exposed to an area of $2 \times 3 \mathrm{~cm}^{2}$ of skin and covered with gauze and plaster.

The rabbits were divided into 6 groups; negative control (F0), positive control (1\% permetrin lotion), $5 \%$ neem oil (F1), 10\% neem oil (F2), 15\% neem oil (F3), and 20\% neem oil (F4). The degree of irritation was assessed at certain time intervals, respectively at 24, 48, and 72 hours after exposure to the test preparation. The degree of irritation was according to WHO testing guidelines and ISO 10998. ${ }^{10}$ The response category was assessed with a primary index BPOM RI. ${ }^{12}$

\section{Eye irritation test}

$0.1 \mathrm{ml}$ of F0, F1, F2, F3, F4, and permetrin were dripped in the conjunctival sack of the rabbit eyes. ${ }^{13}$ Observations were made at 1 , 24, 48, and 72 hours after administration. The parameters observed were effects on the 
Table 1. Primary Irritation Index

\begin{tabular}{clc}
\hline Shampoo & Primary Irritation Index $(\mathbf{n}-15)$ & Response Category \\
\hline F1 & $0(0 \pm 0.43)$ & Very Light \\
F2 & $0.111(0.37 \pm 0.69)$ & Very Light \\
F3 & $0.222(0.62 \pm 0.48)$ & Very Light \\
F4 & $0.222(0.62 \pm 0.85)$ & Very Light \\
\hline
\end{tabular}

Table 2. Average Score of Eyes Observation Value

\begin{tabular}{ccccc}
\hline Shampoo & Cornea & Iris & Conjuctiva & Udema \\
\hline F1 & 0 & 0 & 0.67 & 0 \\
F2 & 0 & 0 & 0.33 & 0 \\
F3 & 0.33 & 0 & 0.67 & 0.33 \\
F4 & 2.33 & 0 & 1.67 & 1.67 \\
& Light Irritant & & & \\
\hline
\end{tabular}

cornea. If the test animal did not show eye injury, the test could be ended on the 3rd day after the administration of the test preparation.

\section{Collection of Headlice and its nits}

Head lice and nits' samples were taken from five pediatric patients in Hegarmanah Village, Jatinangor. Informed consent was signed by the parents. Head lice were taken using a specific comb. Inclusions criteria was patients without head lice treatment at least a month before sampling. Head lice and its nits were collected into petri dish. ${ }^{14}$

\section{Pediculicidal and Ovicidal Activity Assay}

Head lice were divided into 6 groups $(\mathrm{n}=10)$ and inserted into 6 petri dish containing filter paper that has been immersed with F0, F1, F2, F3, F4, and permetrin for 10 minutes. This assay was carried out by following by International Standard. ${ }^{14}$ Mortality rates were calculated by employing previous method. ${ }^{15}$

\section{Results and Discussion}

Physical Properties of Neem Oil Shampoo

The physical properties of neem oil shampoo was viscous (55.76 Ps), yellowish brown, distinctive odor, and $\mathrm{pH} 6.75$.

\section{Acute Dermal Irritation Test}

Based on the results, all shampoo formulas were categorized as very light irritation. Thus, this shampoo formulas were safe to be used. The result is provided in Table 1.

\section{Eyes Irritation Test}

The eye irritation test indicated that neem oil shampoo did not cause any irritation, however the highest concentration showed mild irritant due to its high corneal opacity grade (2.33). The average results of score values is presented in Table 2.

\section{Pediculicidal Activity of Neem Oil Shampoo} F3 and F4 showed $100 \%$ mortality to headlice in shorter time and had similar effect to $1 \%$ permethrin (Table 3).

\section{Ovicidal Activity of Neem Oil Shampoo}

Neem oil shampoo in all concentrations did not show $100 \%$ mortality rate, including $1 \%$ permethrin. F3 and F4 showed 37.5\% mortality, eventhough $1 \%$ permethrin has the highest effectiveness (Table 4).

\section{Conclusion}

Based on the study, it can be concluded that neem oil shampoo in all concentrations were 
Table 3. Neem Oil Shampoo Corrected Mortality

\begin{tabular}{|c|l|c|c|c|c|c|c|c|c|c|c|}
\hline \begin{tabular}{c} 
\%Neem \\
\multirow{2}{*}{$\begin{array}{c}\text { Oil } \\
\text { Shampoo }\end{array}$} \\
\cline { 2 - 14 }
\end{tabular} & \multicolumn{10}{|c|}{ Corrected mortality (\%) n=10 } \\
\hline & 5 & 10 & 20 & 30 & 60 & 120 & 360 & 480 & 720 & 1440 & 2160 \\
\hline F1 & 0 & 13.33 & 10.34 & 31.03 & 37.93 & 60.71 & 70.37 & 85.19 & 100 & 100 & 0 \\
\hline F2 & 6.67 & 13.33 & 24.14 & 31.03 & 52 & 60.71 & 74.07 & 100 & 100 & 100 & 0 \\
\hline F3 & 13.33 & 23.33 & 27.58 & 51.72 & 69 & 75 & 100 & 100 & 100 & 100 & 0 \\
\hline F4 & 13.33 & 23.33 & 31.03 & 58.62 & 86.2 & 96.43 & 100 & 100 & 100 & 100 & 0 \\
\hline Permethrin & 16.67 & 23.33 & 41.38 & 65.52 & 82.76 & 92.86 & 100 & 100 & 100 & 100 & 0 \\
\hline
\end{tabular}

Table 4. Neem Oil Shampoo Corrected Mortality

\begin{tabular}{cc}
\hline Neem Oil & \% Corrected Mortality \\
\hline F1 & 25 \\
F2 & 37.5 \\
F3 & 37.5 \\
F4 & 37.5 \\
Permerthrin & 63 \\
\hline
\end{tabular}

effective as an anti lice. However, the $15 \%$ neem oil shampoo was chosen as the best shampoo because of its high anti lice effect and light irritation response.

\section{Acknowledgements}

None declared.

\section{Conflict of Interest}

None declared.

\section{References}

1. Sembel DT. Entomologi kedokteran edisi I. Yogyakarta: Percetakan Andi; 2009.

2. Handoko RP. Pedikulosis dalam ilmu penyakit kulit dan kelamin edisi III. Jakarta: Balai Penerbit FK UI; 2002.

3. Burkhart $\mathrm{CG}$, Burkhart $\mathrm{CN}$, Burkhart KM. An assessment of topical and oral prescription and over the counter treatments for head lice. Journal of the American Academy of Dermatology. 1998;38(6):979-983.

4. Jones KN, English JC. Review of common therapeutic options in the United
States for the treatment of Pediculosis capitis. Clinical Infectious Diseases. 2003;36(11):1355-1361.

5. Develoux M. Ivermectin. Annales de dermatologie et de vénéréologie. 2004;131(6-7 Pt 1):561-570.

6. Hotson IK. The avermectins: a new family of antiparasitic agents. Journal of South African Veterinary Association. 1982;53(2):87-90.

7. Mac-Mary S, Messikh R, Jeudy A, Lihoreau T, Sainthillier J, Gabard B, Schneider C, Auderset P, Humbert P. Assessment of the efficacy and safety of a new treatment for head lice. International Scholarly Research Network (ISRN) Dermatology. 2012;1-6.

8. Burgess IF. Human lice and their control. Annual Review of Entomology. 2004;49:457-481.

9. Girish K, Shankara BS. Neem - a green treasure. Electronic Journal Biology. 2008;4(3):102-111.

10. Nicoletti M, Petitto V, Gallo FR, Multari G, Federici E, Palazzino G. The modern 
analytical determination of botanicals and similar novel natural products by the HPTLC fingerprint approach. Studies in Natural Product Chemistry. 2012;37:217-258.

11. Brahmachari G. Neem - an omnipotent planta retrospection. Chembiochem. 2004;5:408-421.

12. Cox C. Pyrethrins/pyrethrum insecticide factsheet. Journal of Pesticide Reform. 2002;22:14-20.

13. BPOM RI. Peraturan kepala badan pengawas obat dan makanan republik Indonesia nomor 7 tahun 2014 tentang pedoman uji toksisitas nonklinik secara In Vivo. Jakarta: BPOM RI; 2014.

14. International Standard ISO 1099310. Biological evaluation of medical devices, part 10-tests for irritation and delayed-type hypersensitivity, second Edition. 2002.

15. Kosalge SB, Fursule RA. Investigation of licicidal activity of some plants from Satpuda hills. International Journal of PharmTech Research. 2009;1(3):564567.

16. Kerryn AG, Barnes TM. The efficacy of Australian essential oils for the treatment of head lice infestation in children. Australasian Journal of Dermatology. 2017;59:99-105.

17. Abdel-Ghaffar F. Efficacy of a single treatment of head lice with a neem seed extract: an in vivo and in vitro study on nits and motile stages. Parasitology Research. 2012;110:277-280.

18. Making cosmetics.com.. Shampoo Formulas. [online] Available at: https:// www.makingcosmetics.com/ShampooFormulas_ep_90.html [accessed on November 2018]. 